\title{
Effect of Some Postharvest Treatments on Reducing Chilling Injury of Cucumber Fruits during Cold Storage.
}

\author{
Mohsen EL-Sayed Mohamed Saad \\ Postharvest vegetables Dep. Horti. Res. Inst., ARC, Giza, Egypt. \\ * Corresponding author:mohsenyoukasha@yahoo.com
}

\begin{abstract}
Cucumber (Cucumus sativus, L.)Barakoda F1 hybrid plants were grown under plastic house condition at Experimental Farm for Central Lab. For Agri. Climate in Giza Governorate during two successive of 2017 and 2018 seasons to study the effectof hot water, chitosan, methyl jasmonate, potassium silicate and salicylic acid treatments as postharvest treatments in maintaining the quality and reducing chilling injury (CI) of cucumber fruits during cold storage for 16 days at $5^{\circ} \mathrm{C}$ plus two days at $15^{\circ} \mathrm{C}$.

Cucumber fruits dipped in methyl jasmonate, potassium silicate and salicylic acid did not develop any symptoms of chilling ingury during all storage period plus shelf life. These treatments also maintained fruit firmness, retained more green color, reduced weight loss and did not show any decay until the end of storage period plus shelf life. The onset of CI symptoms in fruits was delayed by hot water and chitosan treatments, these treatments reduced the rate of $\mathrm{CI}$ development. Cucumber fruits dipped in salicylic acid and potassium silicate treatments did not appear changes in their flavor till 12 days, at $5^{\circ} \mathrm{C}+2$ days at $15^{\circ} \mathrm{C}$ and give typical flavor cucumber fruits at the end of storage plus shelf life. Moreover, methyl jasmonate and chitosan or untreated control resulted in non-typical flavor cucumber after $\left(16\right.$ days at $5^{\circ} \mathrm{C}+2$ days at $\left.15^{\circ} \mathrm{C}\right)$. So, salicylic acid or potassium silicate treatments were the most effective treatments in maintaining fruit quality, give typical flavor fruits and gave fruits without decay or CI symptoms and gave good appearance till16 days at $5^{\circ} \mathrm{C}$ plus two days at $15^{\circ} \mathrm{C}$.
\end{abstract}

Key words: cucumber, chilling injury, hot water, chitosan, methyl jasmonate, potassium silicate, salicylic acid, pitting, cold storage.

\section{Introduction}

Chilling injury is an economically important postharvest problem that reduces the overall quality and marketability of many fruit and vegetables. Harvested cucumber (Cucumus sativus L.) fruit are susceptible to chilling injury at temperatures below 7$10^{\circ} \mathrm{C}$. The main chilling injury in cucumber fruits includes surface pitting, the formation of sunken, dark colored, watery areas, rapid chlorophyll breakdown and increased susceptibility to decay and fungal growth (Mao et al., 2007). Chilling sensitive crops can develop symptoms of CI either during storage at chilling temperature or subsequently during marketing condition at non chilling temperature. The development of these chilling disorders reduces consumer acceptance of the fruit, thus limiting storage life and increasing losses.

Several methods have been used to reduce chilling injury in order to extend fruit shelf life and impressive responses have been reported. Among these techniques applied to many horticultural crops, including cucumber, are hot water dips (Shehata et al., 2011), methyl Jasmonate (Gonzalez-Aguilar et al., 2000), potassium silicate (Mditshawaet al., 2013), salicylic acid (Wu and $\mathrm{Wu}$ (2001) and chitosan (Ahmed, 2015). These chemicals are applies to reduce chilling injury. Possible by reinforcing bioactive compounds that detoxify reactive oxygen species (ROS) (Sato et al., 2001). One of the effective bioactive compounds in protecting the fruit from oxidative damage is phenolic.

The use of hot water treatment (HWT) is an accurate method to reduce the development of CI (Ali et al., 2011). Thus, it has been used as a supplement to refrigeration to extend storage and shelf life of cucumber fruits (Hardenburg et al., 1986). The efficiency of hot water treatment that reduces symptoms of CI has been demonstrated by several researchers (Wang, 2006) on zucchini squash, (Abd El-Rahman, 2001;Shehataet al., 2011) on cucumber.The postharvest heat treatments have reported to induce fruit tolerance to cold temperature and to reduce the development of chilling injury symptoms of cucumber during cold storage (Shehataet al., 2011). Hot water treatment has reduce chilling injury (Ilicet al., 2001), reduce weight loss and decay percentage Abd El-Rahman (2001)maintained fruit firmness and inhibited color development and extend shelf life(Wang, 2006).

Another way to maintaining fruit quality and reduce chilling injury is by using chitosan as postharvest treatment. Chitosan is a commercial product;it includes chitosan 90-95\% (2-Amino-2deoxy-beta-D-glucosamine)EL-Badawy(2014).

Chitosan treatment has been confirmed to be a useful tool for postharvest fruit quality maintenance, by preventing water loss and fruit softening, delay ripening (Dong et al., 2004).Chitosan treatment has reduced decay incidence and inhibit fruit respiration. 
Chitosan maintain color and extend the shelf life (Fard et al., 2010) also been proven to effectively reduce chilling injury symptoms in fruit (MengMeng et al., 2012).

Jasmonic acid (JA) and methyl jasmonate (MeJA), arecyclopentenonc compounds and are regarded as natural occurring plant growth regulators (Sembdner and Parthier, 1993). Methyl jasmoineoil is alleviating CI by increasing the expression of a set of defenses genes and enhancing the antioxidant capacity in horticultural crops. Ghasemnezhad and Javahersashti (2008) were expressed that MeJA could enhance the total phenolic and therefore induce the defense mechanism of raspberry against low temperature stress. Methyl jasmonate seem to be effective in delaying the onset and reducing the severity of CI symptoms in zucchini squashes (Wang, 2006), also Rageh and Abou-Elwafa, 2017 found that cucumber fruits obtained from plants treated withMeJA reduced CI symptoms for 8 days of storage +2 days $20^{\circ} \mathrm{C}$. Hamdyet al. (2015) on squash fruits treated with MeJA decreased the incidence of CI symptoms and decay of fruit during cold storage at $20^{\circ} \mathrm{C}$. MeJA play an integraltale in the intracellular signal transduction cascade which acts in the inducible defense mechanisms that plants have developed against pathogens and other stresses.

Salicylic acid (SA) is a natural and safe simple phenolic compound, exhibits a high potential in controlling postharvest losses of horticultural crops (Asghari and Aghdam, 2010). SA is also a signaling molecule which induces biosynthesis of defense compounds such as poly phenols and pathogenesis related proteins (Yao and Tian, 2005). Moreover, SA involved in activation of the stress induced antioxidant system when plants are exposed to salicylic acid treatment could be used to reduce deterioration and chilling injury symptoms in some fruits (Yang et al., 2012), postharvest application with $\mathrm{SA}$ at $2 \mathrm{mM}$ concentration was highly effective in reducing chilling injury incidence and decay of cold stored pomegranate fruits at $2^{\circ} \mathrm{C}$ for 3 months (Sayyari et al., 2011).

Recently, silicon ( $\mathrm{Si}$ ) has been shown to induce resistance to both biotic and a biotic stress. There is ample experimental evidence suggesting that $\mathrm{Si}$ affects the activity of major antioxidant enzyme involved in plant stress defense systems (Crusciolet al., 2009;Epstein, 2009). Also Mditshwaet al., (2013) found that lemon fruits dipped in potassium silicate reduced chilling injury symptoms in fruits during cold storage.

Therefore, this study was undertaken to determine the effectiveness of hot water, chitosan, methyl jasmonate, potassium silicate and salicylic acid treatments as postharvest treatments in maintaining the quality and reducing chilling injury of cucumber fruits during cold storage for 16 days plus two days at $15^{\circ} \mathrm{C}$.

\section{Material and methods}

Cucumber (Cucumus sativus, L.)Barakoda F1 hybrid plants were grown under plastic house condition at Experimental Farm for Central Lab. For Agri. Climate in Giza Governorate during two successive of 2017 and 2018. Seeds were sown in nursery on $10^{\text {th }}$ and $14^{\text {th }}$ at September 2017 and 2018 seasons, respectively. Seedlings were transplanted on $25^{\text {th }}$ and $28^{\text {th }}$ on September in the first and second season, respectively. Normal cultural practices were carried out wherever it was needed according to the recommendation of Ministry of Agriculture, Egypt.

Cucumber fruits were harvested at the proper stage of maturity (on November $1^{\text {st }}$ and $4^{\text {th }}$ in the first and second season, respectively) then transferred to laboratory of Postharvest and Handling of Vegetable Crops Department Hort. Res. Inst. at Giza, Egypt. Fruits were selected for their fruits uniformity of size (12 - $14 \mathrm{~cm}$ in length and $3.5-4 \mathrm{~cm}$ in diameter) and free of visual damage of defects for the following treatments:

1- Dipping in solution of chitosan at $0.5 \%$ for $5 \mathrm{~min}$.

2- Dipping in solution of salicylic acid (SA) at $2 \mathrm{mM}$ for $5 \mathrm{~min}$.

3- Dipping in hot water at $45^{\circ} \mathrm{C}$ for $5 \mathrm{~min}$.

4- Dipping in solution of methyl jasmonate at 0.1 $\mathrm{mM}$ for $3 \mathrm{~min}$.

5- Dipping in solution of potassium silicate at $100 \mathrm{mg}$ / L for $7.5 \mathrm{~min}$.

6- Untreated fruits (dipped in distilled water) control. All treatments of fruits were air dried, then packed in polypropylene bags $(25 \times 30 \mathrm{~cm})$ and $30 \mathrm{MU}$ thickness. Each bag contains7 fruits represented as experimental unit (EU). Twelve EU were prepared for each treatment and stored at $5^{\circ} \mathrm{C}$ and $95 \%$ relative humidity (RH). Samples were taken randomly in three replicates EU and were arranged in complete randomized design. Measurement, were examined immediately after harvest and at 4 days intervals $\left(0,4,8,12\right.$ and 16 days) of storage at $5^{\circ} \mathrm{C}$ in addition to 2 days at $15^{\circ} \mathrm{C}$ (shelf life conditions) for the following characteristics.

Weight loss (\%): It was calculated according to the equation: $=[($ initial weight of fruits - weight of fruits at sampling data)/ (initial weight of fruits)] x100.

General appearance: General appearance was evaluated using a scale from (1-9) with $9=$ excellent, $7=$ good, $5=$ fair, $3=$ poor, $1=$ unsalable and fruits rating (5) or below were considered unmarketable.

Decay score: Decay was determined using the following score 1=no decay, 2=slight, 3=moderate, 4=sever and 5=extreme (Wang and Qi, 1997).

Color: Color was measured on two sides of each fruit by using Minolta CR-400 Chroma Meter (Minolta Co. ltd. Osaka, Japan). The measurements of skin color and gloss were expressed in chromaticity values of hue angle $\left(\mathrm{h}^{\circ}\right)$ and lightness $(\mathrm{L})$, respectively. Three readings were taken at different locations of each cucumber fruit during each data observation (McGuire, 1992). 
Chilling injury: The degree of chilling injury, as judged by the extent of surface pitting was evaluated five hours after transfer of cucumber fruits from $5^{\circ} \mathrm{C}$ to $15^{\circ} \mathrm{C}$ by rating scale of 1 to 5 , where $1=$ no pitting, $2=10 \%$ of the surface area pitted, $3=11-25 \%$ of the surface area pitted, $4=26-50 \%$ of the area pitted $5=\geq$ $50 \%$ of the surface area pitted (as describe by Wang and Qi, 1997).

Fruit firmness: Fruit firmness was measured in Lp/in ${ }^{2}$ by Magness and Ballouf pressure tester equipped with $3 / 16$ inch plunger and adjusted in Newton as recommended by (ASHS postharvest working Group).

Flavor: Flavor was determined according to the following score $1=$ none, $2=$ slight, $3=$ moderate, $4=$ moderate full and $5=$ full typical tasting as described bycantwellet al.(2009).

\section{Statistical analysis:}

Data were statistically analyzed using the analysis of variance described by Snedecor and Cochran (1980). The method of Duncan multiple range tests were applied for than comparison between means according to Waller and Duncan (1969).

\section{Results and discussion}

\section{Weight loss percentage:}

Data in Table (1) revealed that weight loss (\%) of cucumber fruits was increased considered and consistently with the prolongation of storage period plus shelf life in the two seasons. These results are in agreement with privies researcher(Shehata et al., 2004 andRageh and Abou-Elwafa, 2017). The loss in weight may be due to transpiration, respiration and other senescence related metabolic processes during storage (Wills et al., 1981).

Concerning the effect of postharvest treatments, data showed that there were significant differences among treatments in weight loss \% during storage. All postharvest treatments reduced weight loss $\%$ as compared with untreated control during storage and shelf life. Moreover, cucumber fruits dipped in chitosan, salicylic acid (SA) and potassium silicate were the most effective treatments in reducing the weight loss percentage followed by methyl Jasmonate. Hot water treatment was less effective in this concern. These results were achieved in the two seasons and were in agreement with those reported by Shehataet al. (2011) for hot water MengMenget al., (2012) for chitosan Rageh and Abou-Elwafa (2017), for methyl jasmonate (Mditshwaet al., 2013) for potassium silicate Shoor, (2010) for salicylic acid.

Table 1. Effect of some postharvest treatments on weight loss percentage of cucumber fruits during cold storage plus shelf life in 2017 and 2018 seasons.

\begin{tabular}{|c|c|c|c|c|c|c|c|}
\hline \multirow{3}{*}{ Treatments } & \multicolumn{6}{|c|}{ Storage period (days) } & \multirow{3}{*}{ Mean } \\
\hline & \multicolumn{6}{|c|}{2017} & \\
\hline & $\mathbf{0}$ & $0+2$ & $4+2$ & $8+2$ & $12+2$ & $16+2$ & \\
\hline Hot water & $0.00 \mathrm{P}$ & $0.17 \mathrm{~N}$ & $0.84 \mathrm{G}$ & $1.08 \mathrm{E}$ & $1.42 \mathrm{C}$ & $1.78 \mathrm{~B}$ & $0.88 \mathrm{~B}$ \\
\hline Methyl Jasmonate & $0.00 \mathrm{P}$ & $0.12 \mathrm{NO}$ & $0.69 \mathrm{IJ}$ & $0.86 \mathrm{G}$ & $1.22 \mathrm{D}$ & $1.42 \mathrm{C}$ & $0.72 \mathrm{C}$ \\
\hline Potassium silicate & $0.00 \mathrm{P}$ & $0.09 \mathrm{O}$ & $0.40 \mathrm{~L}$ & $0.63 \mathrm{~J}$ & $0.80 \mathrm{GH}$ & $1.08 \mathrm{E}$ & $0.50 \mathrm{D}$ \\
\hline Chitosan & $0.00 \mathrm{P}$ & $0.09 \mathrm{O}$ & $0.36 \mathrm{LM}$ & $0.55 \mathrm{~K}$ & $0.76 \mathrm{HI}$ & $0.96 \mathrm{~F}$ & $0.45 \mathrm{E}$ \\
\hline Salicylic acid & $0.00 \mathrm{P}$ & $0.10 \mathrm{NO}$ & $0.33 \mathrm{LM}$ & $0.64 \mathrm{~J}$ & $0.80 \mathrm{GH}$ & $1.00 \mathrm{~F}$ & $0.48 \mathrm{DE}$ \\
\hline Control & $0.00 \mathrm{P}$ & $0.30 \mathrm{M}$ & $1.11 \mathrm{E}$ & $1.48 \mathrm{C}$ & $1.84 \mathrm{~B}$ & $2.26 \mathrm{~A}$ & $1.17 \mathrm{~A}$ \\
\hline Mean & $0.00 \mathrm{~F}$ & 0.15 E & 0.62 D & $0.87 \mathrm{C}$ & $1.14 \mathrm{~B}$ & $1.42 \mathrm{~A}$ & \\
\hline \multicolumn{8}{|c|}{2018} \\
\hline Hot water & $0.00 \mathrm{P}$ & $0.16 \mathrm{~N}$ & $0.83 \mathrm{H}$ & $1.06 \mathrm{EF}$ & $1.41 \mathrm{C}$ & $1.77 \mathrm{~B}$ & $0.87 \mathrm{~B}$ \\
\hline Methyl Jasmonate & $0.00 \mathrm{P}$ & $0.10 \mathrm{NO}$ & $0.67 \mathrm{~J}$ & $0.84 \mathrm{H}$ & $1.20 \mathrm{D}$ & $1.40 \mathrm{C}$ & $0.70 \mathrm{C}$ \\
\hline Potassium silicate & $0.00 \mathrm{P}$ & $0.09 \mathrm{O}$ & $0.39 \mathrm{~L}$ & $0.62 \mathrm{~J}$ & $0.78 \mathrm{HI}$ & $1.06 \mathrm{EF}$ & $0.49 \mathrm{D}$ \\
\hline Chitosan & $0.00 \mathrm{P}$ & $0.09 \mathrm{O}$ & $0.35 \mathrm{LM}$ & $0.53 \mathrm{~K}$ & $0.75 \mathrm{I}$ & $0.96 \mathrm{G}$ & $0.45 \mathrm{E}$ \\
\hline Salicylic acid & $0.00 \mathrm{P}$ & $0.10 \mathrm{NO}$ & $0.33 \mathrm{LM}$ & $0.64 \mathrm{~J}$ & $0.79 \mathrm{HI}$ & $1.01 \mathrm{FG}$ & $0.48 \mathrm{D}$ \\
\hline Control & $0.00 \mathrm{P}$ & $0.28 \mathrm{M}$ & $1.10 \mathrm{E}$ & $1.46 \mathrm{C}$ & $1.83 \mathrm{~B}$ & $2.22 \mathrm{~A}$ & $1.15 \mathrm{~A}$ \\
\hline Mean & $0.00 \mathrm{~F}$ & 0.14 E & $0.61 \mathrm{D}$ & $0.86 \mathrm{C}$ & $1.13 \mathrm{~B}$ & $1.40 \mathrm{~A}$ & \\
\hline
\end{tabular}

Means in the same column having the same letter are not significantly different at 0.05 levels by Duncan's multiple rang test.

The application of exogenous organic acids such as salicylic acid has been found to affect fruit quality and induce stress tolerance (Shoor, 2010). These organic acids mainly function in maintaining the ability to inhibit $\mathrm{O}_{2}$ accumulation, delaying $\mathrm{H}_{2} \mathrm{O}_{2}$ decrease and enhancing antioxidant enzyme activities with an increase in the expression of senescence related proteins or defense proteins to keeps the fruit in good quality during storage (Dinget al., 2009; Tareenet al., 2012a).

The favorable effect of potassium silicate in reduction of weight loss was probably due to the modification of cell membranes after Si application that led to reduction of water loss and subsequently 
reduced fruit weight loss (Epstein, 2009). Silicon application also reduced electrolyte leakage in rice leaves. This may be attributed to the improved strength and rigidity of tissue following Si application (Liang et al., 2007).

Baldwin et al. (1995) found that chitosan coating significantly reduced weight loss during storage as it enables epidermal tissues to control water loss and reduce respiratory exchange, barrier to water vapor, reducing moisture loss and delaying fruit dehydration,there by resulting in lower weight loss (Shiri et al. 2013).

The reducing weight loss \% by using methyl jasmonate treatments may be attributed to reducing the respiration process during storage (Yao and Tian (2005), which slow down the metabolic processes (Hamdyet al.2015), which diminished the weight loss during storage.

In general, the interaction between postharvest treatments and storage period plus shelf life was significant in the two seasons. Cucumber fruits dipped in chitosan or salicylic acid reduced weight loss percentage of fruits during all storage period with no significant differences between them, followed by potassium silicate treatment. On the other hand, the highest values of weight loss percentage are recorded from untreated control. These results were achieved in the two seasons.

\section{General appearance (score):}

Data in Table (2) indicated that general appearance (GA) of cucumber fruits deceased with the prolongation of storage period plus shelf life. Similar results were reported by Rageh and Abou-Elwafa (2017) on cucumber. The decrease of general appearance of cucumber fruits during storage might be due to shriveling, pitting, color change of fruits and decay (Shehataet al., 2011).
Concerning the effect of postharvest treatments, data revealed that cucumber fruits treated with all postharvest treatments had significantly the highest score of appearance as compared with untreated control. However, cucumber fruits dipped in salicylic acid, potassium silicate and methyl jasmonate were the most effective treatments for maintaining GA with no significant differences between them followed by chitosan or hot water treatments with no significant differences between them, while untreated control recorded the lowest ones in this concern. These results were achieved in the two seasons and were in agreement with (Shehataet al., 2011, for hot water, MengMenget al., 2012, for chitosan, Rageh and Abou-Elwafa, 2017, for methyl jasmonate, Mditshwaet al., 2013, for potassium silicate andShoor, (2010) for salicylic acid).

The application of SA treatment showed the greatest on activity of POX enzyme and lowest activity of PPO enzyme as compared with untreated control may be helpful for minimizing the utilization of antioxidants used for the scavenging of the free radicals. Senescence or stress condition coincided with membrane damage in fits(Mayer, 1987). It was proposed that the increase in the activity of POX enzyme and decrease in activity of PPO enzyme with lowest chilling injury were generally a consequence of the system ability to delay senescence during cold storage and increase marketable fruits.

Kaluwaet al. (2010) found that the main effect of silicon application lies in suppression of respiration and ethylene production. Therefore, improving $\mathrm{Si}$ infiltration techniques could enhance shelf life of fruits. They add that Si increases antioxidant and total phenolics accumulation in the fruit, thereby, increasing the stress relieving ability of the fruit, producing fruit with a higher ability to withstand longterm storage.

Table 2. Effect of some postharvest treatments on general appearance (score) of cucumber fruitsduring cold storage plus shelf life in 2017 and 2018 seasons.

\begin{tabular}{|c|c|c|c|c|c|c|c|}
\hline \multirow{3}{*}{ Treatments } & \multicolumn{6}{|c|}{ Storage period (days) } & \multirow{3}{*}{ Mean } \\
\hline & \multicolumn{6}{|c|}{2017} & \\
\hline & $\mathbf{0}$ & $0+2$ & $4+2$ & $8+2$ & $12+2$ & $16+2$ & \\
\hline Hot water & $9.00 \mathrm{~A}$ & $9.00 \mathrm{~A}$ & $8.33 \mathrm{AB}$ & $7.67 \mathrm{BC}$ & $6.33 \mathrm{D}$ & $3.67 \mathrm{~F}$ & $7.33 \mathrm{~B}$ \\
\hline Methyl Jasmonate & $9.00 \mathrm{~A}$ & $9.00 \mathrm{~A}$ & $9.00 \mathrm{~A}$ & $9.00 \mathrm{~A}$ & $8.33 \mathrm{AB}$ & $7.00 \mathrm{CD}$ & $8.56 \mathrm{~A}$ \\
\hline Potassium silicate & $9.00 \mathrm{~A}$ & $9.00 \mathrm{~A}$ & $9.00 \mathrm{~A}$ & $8.33 \mathrm{AB}$ & $7.67 \mathrm{BC}$ & $7.00 \mathrm{CD}$ & $8.33 \mathrm{~A}$ \\
\hline Chitosan & $9.00 \mathrm{~A}$ & $9.00 \mathrm{~A}$ & $9.00 \mathrm{~A}$ & $7.67 \mathrm{BC}$ & $5.00 \mathrm{E}$ & $3.00 \mathrm{~F}$ & 7.11 B \\
\hline Salicylic acid & $9.00 \mathrm{~A}$ & $9.00 \mathrm{~A}$ & $9.00 \mathrm{~A}$ & $8.33 \mathrm{AB}$ & $7.67 \mathrm{BC}$ & $7.00 \mathrm{CD}$ & $8.33 \mathrm{~A}$ \\
\hline Control & $9.00 \mathrm{~A}$ & $9.00 \mathrm{~A}$ & $7.67 \mathrm{BC}$ & $5.00 \mathrm{E}$ & $1.67 \mathrm{G}$ & $1.00 \mathrm{G}$ & $5.56 \mathrm{C}$ \\
\hline \multirow{2}{*}{ Mean } & $9.00 \mathrm{~A}$ & $9.00 \mathrm{~A}$ & 8.67 B & $7.67 \mathrm{C}$ & 6.11 D & $4.78 \mathrm{E}$ & \\
\hline & \multicolumn{6}{|c|}{2018} & \\
\hline Hot water & $9.00 \mathrm{~A}$ & $9.00 \mathrm{~A}$ & $9.00 \mathrm{~A}$ & $7.67 \mathrm{BC}$ & $5.67 \mathrm{D}$ & $4.33 \mathrm{E}$ & $7.44 \mathrm{~B}$ \\
\hline Methyl Jasmonate & $9.00 \mathrm{~A}$ & $9.00 \mathrm{~A}$ & $9.00 \mathrm{~A}$ & $9.00 \mathrm{~A}$ & $8.33 \mathrm{AB}$ & $7.00 \mathrm{C}$ & $8.56 \mathrm{~A}$ \\
\hline Potassium silicate & $9.00 \mathrm{~A}$ & $9.00 \mathrm{~A}$ & $9.00 \mathrm{~A}$ & $9.00 \mathrm{~A}$ & $8.33 \mathrm{AB}$ & $7.00 \mathrm{C}$ & $8.56 \mathrm{~A}$ \\
\hline Chitosan & $9.00 \mathrm{~A}$ & $9.00 \mathrm{~A}$ & $9.00 \mathrm{~A}$ & $7.67 \mathrm{BC}$ & $5.67 \mathrm{D}$ & $3.00 \mathrm{~F}$ & $7.22 \mathrm{~B}$ \\
\hline Salicylic acid & $9.00 \mathrm{~A}$ & $9.00 \mathrm{~A}$ & $9.00 \mathrm{~A}$ & $8.33 \mathrm{AB}$ & $8.33 \mathrm{AB}$ & $7.67 \mathrm{BC}$ & $8.56 \mathrm{~A}$ \\
\hline Control & $9.00 \mathrm{~A}$ & $9.00 \mathrm{~A}$ & $8.33 \mathrm{AB}$ & $5.67 \mathrm{D}$ & $2.33 \mathrm{~F}$ & $1.00 \mathrm{G}$ & $5.89 \mathrm{C}$ \\
\hline
\end{tabular}




$\begin{array}{lllllll}\text { Mean } & 9.00 \mathrm{~A} & 9.00 \mathrm{~A} & \mathbf{8 . 8 9} \mathrm{A} & \mathbf{7 . 8 9} \mathrm{B} & \mathbf{6 . 4 4} \mathrm{C} & \mathbf{5 . 0 0} \mathrm{D}\end{array}$

Means in the same column having the same letter are not significantly different at 0.05 levels by Duncan's multiple rang test

Chitosan coating acts as a semipermeable barrier on the surface of fruit and vegetables against oxygen, carbon dioxide and moisture, thereby reducing respiration, water loss, respiratory activity and degradation by enzymes and microbial rot of fruits, counteracting the dehydration and shrinkage of the fruit, and ethylene production and maintaining the overall quality and prolonging the shelf life (Velickova et al., 2013).

In general, the interaction between postharvest treatments and storage periods plus shelf life was significant in the two seasons. Results indicated that cucumber fruits dipped in salicylic acid, potassium silicate and methyl jasmonate showed the best appearance which gave good appearance at the end of storage period plus shelf life ( 16 days at $5^{\circ} \mathrm{C}+2$ days at $\left.15^{\circ} \mathrm{C}\right)$, while chitosan and hot water treatments rated good appearances after 8 days at $5^{\circ} \mathrm{C}+2$ days at $15^{\circ} \mathrm{C}$. On the other hand, untreated control had the unsalable appearance at the end of storage period plus shelf life.

\section{Decay percentage:}

Data in Table (3) showed that there were significant increases in decay percentage with the prolongation of storage period plus shelf life in the two seasons (Table1 2). These results were in agreement with Rageh and Abou-Elwafa (2017)on cucumber and may be due to the continuous chemical and biochemical changes happened in fruits such as transformation of complex compounds to simple forms of a more liability to fungal infection (Wills et al., 1981).

There were significant differences among postharvest treatments on decay percentage during storage plus shelf life. All postharvest treatments were much better in reducing decay percentage and so longer storage period compared with untreated control. However cucumber fruits treated with methyl jasmonate or SA and potassium silicate did not show any decay until the end of storage period plus shelf life in the two seasons. Fruits treated with hot water and chitosan reduced the incidence of decay $\%$ with significant differences between them in the two seasons, while untreated control gave the highest decay $\%$. These results were true in the two seasons and are in agreement with Afifi (2016) for potassium silicate Rageh and Abou-Elwafa (2017) for methyl jasmonate, Yassin et al., (2017) for hot water, Mohamed et al., (2016) for salicylic acid and GadElrab (2018) for chitosan.

Ghasemnezhad and Javaherdashti, 2008, demonstrated that MeJA increases the resistance of tissues against decay by enhancing their antioxidant system and their free radical scavenging capability. Also, Ding et al. (2002) reported that treatment of tomato fruits with MeJA induced the expression of pathogenesis related-proteins including B-1,3 glucanase and chitinass leading to increased chilling tolerance and resistance to pathogens, thereby reducing the incidence of fruit decay during storage.

Also there are many reports indicating that SA is an endogenous signal for the activation of certain plant defense responses and is able to enhance disease resistance Yao\&Tian (2005). The reduce in decayed fruits treated with SA may be due to an increase in activity of POX enzyme and decrease activities in PPO and PE enzyme of Valencia oranges during cold storage.

As for the effect of potassium silicate, Tarabihet al. (2014) found that potassium silicate increase the concentration of antifungal compounds and or the enzyme PAL to be able to increase the concentration of phenolic compounds present at later ripening stages in order to decrease decay incidence in apple fruit.

The favorable effect of chitosan treatments in reducing decay of cucumber, may be due to chitosan coating, can inhibit the increase of oxidative enzyme (peroxidase and polyphenol oxidase) activity. An increase in antioxidant enzyme activity and free radical scavenging capacity during storage would reduce the physiological deterioration and enhance the resistance of tissue against microbial invasion and reduce the spoilage of fruit (Xing et al., 2011).

Table 3. Effect of some postharvest treatments on decay percentage of cucumber fruits during cold storage plusshelf life in 2017 and 2018 seasons.

\begin{tabular}{|c|c|c|c|c|c|c|c|}
\hline \multirow{3}{*}{ Treatments } & \multicolumn{6}{|c|}{ Storage period (days) } & \multirow{3}{*}{ Mean } \\
\hline & \multicolumn{6}{|c|}{2017} & \\
\hline & $\mathbf{0}$ & $0+2$ & $4+2$ & $8+2$ & $12+2$ & $16+2$ & \\
\hline Hot water & $0.00 \mathrm{~F}$ & $0.00 \mathrm{~F}$ & $0.00 \mathrm{~F}$ & $0.00 \mathrm{~F}$ & $0.00 \mathrm{~F}$ & $9.62 \mathrm{D}$ & $1.60 \mathrm{C}$ \\
\hline Methyl Jasmonate & $0.00 \mathrm{~F}$ & $0.00 \mathrm{~F}$ & $0.00 \mathrm{~F}$ & $0.00 \mathrm{~F}$ & $0.00 \mathrm{~F}$ & $0.00 \mathrm{~F}$ & $0.00 \mathrm{D}$ \\
\hline Potassium silicate & $0.00 \mathrm{~F}$ & $0.00 \mathrm{~F}$ & $0.00 \mathrm{~F}$ & $0.00 \mathrm{~F}$ & $0.00 \mathrm{~F}$ & $0.00 \mathrm{~F}$ & $0.00 \mathrm{D}$ \\
\hline Chitosan & $0.00 \mathrm{~F}$ & $0.00 \mathrm{~F}$ & $0.00 \mathrm{~F}$ & $0.00 \mathrm{~F}$ & $0.00 \mathrm{~F}$ & $13.60 \mathrm{~B}$ & $2.27 \mathrm{~B}$ \\
\hline Salicylic acid & $0.00 \mathrm{~F}$ & $0.00 \mathrm{~F}$ & $0.00 \mathrm{~F}$ & $0.00 \mathrm{~F}$ & $0.00 \mathrm{~F}$ & $0.00 \mathrm{~F}$ & $0.00 \mathrm{D}$ \\
\hline Control & $0.00 \mathrm{~F}$ & $0.00 \mathrm{~F}$ & $0.00 \mathrm{~F}$ & $2.67 \mathrm{E}$ & $11.33 \mathrm{C}$ & $21.18 \mathrm{~A}$ & $5.86 \mathrm{~A}$ \\
\hline Mean & $0.00 \mathrm{D}$ & $0.00 \mathrm{D}$ & $0.00 \mathrm{D}$ & $0.44 \mathrm{C}$ & $1.89 \mathrm{~B}$ & $7.40 \mathrm{~A}$ & \\
\hline
\end{tabular}




\begin{tabular}{lccccccc}
\hline & \multicolumn{7}{c}{$\mathbf{2 0 1 8}$} \\
\hline Hot water & $0.00 \mathrm{~F}$ & $0.00 \mathrm{~F}$ & $0.00 \mathrm{~F}$ & $0.00 \mathrm{~F}$ & $0.00 \mathrm{~F}$ & $8.91 \mathrm{D}$ & $\mathbf{1 . 4 9} \mathbf{C}$ \\
Methyl Jasmonate & $0.00 \mathrm{~F}$ & $0.00 \mathrm{~F}$ & $0.00 \mathrm{~F}$ & $0.00 \mathrm{~F}$ & $0.00 \mathrm{~F}$ & $0.00 \mathrm{~F}$ & $\mathbf{0 . 0 0} \mathrm{D}$ \\
Potassium silicate & $0.00 \mathrm{~F}$ & $0.00 \mathrm{~F}$ & $0.00 \mathrm{~F}$ & $0.00 \mathrm{~F}$ & $0.00 \mathrm{~F}$ & $0.00 \mathrm{~F}$ & $\mathbf{0 . 0 0} \mathrm{D}$ \\
Chitosan & $0.00 \mathrm{~F}$ & $0.00 \mathrm{~F}$ & $0.00 \mathrm{~F}$ & $0.00 \mathrm{~F}$ & $0.00 \mathrm{~F}$ & $12.01 \mathrm{~B}$ & $\mathbf{2 . 0 0} \mathrm{B}$ \\
Salicylic acid & $0.00 \mathrm{~F}$ & $0.00 \mathrm{~F}$ & $0.00 \mathrm{~F}$ & $0.00 \mathrm{~F}$ & $0.00 \mathrm{~F}$ & $0.00 \mathrm{~F}$ & $\mathbf{0 . 0 0} \mathrm{D}$ \\
Control & $0.00 \mathrm{~F}$ & $0.00 \mathrm{~F}$ & $0.00 \mathrm{~F}$ & $2.33 \mathrm{E}$ & $10.20 \mathrm{C}$ & $19.82 \mathrm{~A}$ & $\mathbf{5 . 3 9} \mathrm{A}$ \\
Mean & $\mathbf{0 . 0 0} \mathrm{D}$ & $\mathbf{0 . 0 0} \mathrm{D}$ & $\mathbf{0 . 0 0} \mathrm{D}$ & $\mathbf{0 . 3 9} \mathrm{C}$ & $\mathbf{1 . 7 0 ~ B}$ & $\mathbf{6 . 7 9} \mathrm{A}$ & \\
\hline
\end{tabular}

Means in the same column having the same letter are not significantly different at 0.05 level by Duncan's multiple rang test

Dipping the fruits in hot water resulted in some decrease in decay and fungal development may be related to washing off the natural pathogenic spore population from the surface of fruit, (Cantwell and Nie, 1992) on tomato. However, such a dip may also remove part of the natural antagonistic flora inhibiting the fruit peel which may act as a bio control agent of postharvest pathogens (Harvey et al., 1989).

Color ( $L$ value)

Data in Table (4) showed that there was a significant decrease in $\mathrm{L}$ value with increasing storage period for all postharvest or control, showing darker fruits. These results were true in the two seasons and in agreement with Rageh and Abo-Elwafa (2017). These results may be attributed to potassium silicate which delayed fruit senescence in which the external and internal color was lighter than of untreated control.

Also, Hamdyet al. (2015) found that jasmine oil vapor effectively maintained squash fruit brightness for 9 days during cold storage period, as jasmine vapor exposed fruits displayed more shiny and bright appearance than control fruits.
Fardet al. (2010) found that chitosan coating reduced the loss of color for the bell pepper and delayed the deterioration of green pepper as judged by external appearance. Also, Xing et al. (2011) revealed that chitosan coating exhibited better control effect on the reduced chlorophyll content in sweet pepper. The retardation of color development in fruit reduced ethylene productions leading to a modified internal atmosphere of the fruit (Fardet al., 2010) and then retarding the ripening process, this in turn, delayed color loss.However, all postharvest treatments significantly reduced the loss of $\mathrm{L}$ value compared with untreated control. Cucumber fruits treated with methyl jasmonate, potassium silicate or salicylic acid had significant higher $\mathrm{L}$ value indicating lighter fruits with no significant difference between them in the first season, followed by chitosan treatment during cold storage plus shelf life, Hot water was less effective in this concern, while untreated control had darker color (low $\mathrm{L}$ value).

Tareenet al. (2012b) found that peach fruits illustrated that immersing in SA solution reduced the changes in fruits color and maintains fruits lightness during cold storage.

Table 4. Effect of some postharvest treatments on color b change (L value) of cucumber fruits during cold storage plus shelf life in 2017 and 2018 seasons.

\begin{tabular}{|c|c|c|c|c|c|c|c|}
\hline \multirow{3}{*}{ Treatments } & \multicolumn{6}{|c|}{ Storage period (days) } & \multirow{3}{*}{ Mean } \\
\hline & \multicolumn{6}{|c|}{2017} & \\
\hline & $\mathbf{0}$ & $0+2$ & $4+2$ & $8+2$ & $12+2$ & $16+2$ & \\
\hline Hot water & $43.00 \mathrm{~A}$ & $42.02 \mathrm{~A}-\mathrm{D}$ & $40.90 \mathrm{~B}-\mathrm{H}$ & 40.10 D-J & $39.30 \mathrm{G}-\mathrm{L}$ & $37.40 \mathrm{LM}$ & $40.45 \mathrm{C}$ \\
\hline Methyl Jasmonate & $43.00 \mathrm{~A}$ & $42.82 \mathrm{AB}$ & $42.64 \mathrm{AB}$ & $41.80 \mathrm{~A}-\mathrm{D}$ & $41.00 \mathrm{~A}-\mathrm{H}$ & 40.10 D-J & $41.89 \mathrm{~A}$ \\
\hline Potassium silicate & $43.00 \mathrm{~A}$ & $42.87 \mathrm{AB}$ & $42.30 \mathrm{~A}-\mathrm{C}$ & $41.00 \mathrm{~A}-\mathrm{H}$ & 40.20 D-J & $38.80 \mathrm{I}-\mathrm{L}$ & 41.36 AB \\
\hline Chitosan & $43.00 \mathrm{~A}$ & $42.41 \mathrm{~A}-\mathrm{C}$ & $41.50 \mathrm{~A}-\mathrm{F}$ & 40.40 C-I & $39.70 \mathrm{E}-\mathrm{K}$ & $38.30 \mathrm{~J}-\mathrm{L}$ & 40.89 BC \\
\hline Salicylic acid & $43.00 \mathrm{~A}$ & $42.90 \mathrm{AB}$ & $42.68 \mathrm{AB}$ & 41.67 A-E & $41.20 \mathrm{~A}-\mathrm{G}$ & $39.60 \mathrm{~F}-\mathrm{K}$ & $41.84 \mathrm{~A}$ \\
\hline Control & $43.00 \mathrm{~A}$ & 41.20 A-G & $39.60 \mathrm{~F}-\mathrm{K}$ & $39.12 \mathrm{H}-\mathrm{L}$ & $37.90 \mathrm{KL}$ & $35.40 \mathrm{M}$ & 39.37 D \\
\hline \multirow[t]{2}{*}{ Mean } & $43.00 \mathrm{~A}$ & $42.37 \mathrm{AB}$ & 41.60 B & $40.68 \mathrm{C}$ & $39.88 \mathrm{C}$ & 38.27 D & \\
\hline & \multicolumn{6}{|c|}{2018} & \\
\hline Hot water & $46.00 \mathrm{~A}$ & $43.22 \mathrm{D}-\mathrm{G}$ & $42.10 \mathrm{H}-\mathrm{L}$ & $41.30 \mathrm{LM}$ & $40.50 \mathrm{M}-\mathrm{O}$ & $38.60 \mathrm{P}$ & 41.95 D \\
\hline Methyl Jasmonate & $46.00 \mathrm{~A}$ & 44.03 B-D & $43.51 \mathrm{C}-\mathrm{F}$ & $42.70 \mathrm{~F}-\mathrm{J}$ & 42.07 I-L & $40.77 \mathrm{MN}$ & 43.18 B \\
\hline Potassium silicate & $46.00 \mathrm{~A}$ & 44.47 B & $43.90 \mathrm{~B}-\mathrm{E}$ & $42.60 \mathrm{G}-\mathrm{K}$ & $41.80 \mathrm{~J}-\mathrm{L}$ & $40.40 \mathrm{M}-\mathrm{O}$ & 43.19 B \\
\hline Chitosan & $46.00 \mathrm{~A}$ & 43.91 B-D & $43.00 \mathrm{E}-\mathrm{H}$ & $41.90 \mathrm{I}-\mathrm{L}$ & 41.20 LM & $39.80 \mathrm{O}$ & 42.64 C \\
\hline Salicylic acid & $46.00 \mathrm{~A}$ & $44.50 \mathrm{~B}$ & $44.28 \mathrm{BC}$ & 43.27 D-G & $42.80 \mathrm{~F}-\mathrm{I}$ & $41.20 \mathrm{LM}$ & 43.67 A \\
\hline Control & $46.00 \mathrm{~A}$ & $41.70 \mathrm{KL}$ & $40.10 \mathrm{NO}$ & $39.62 \mathrm{O}$ & $38.40 \mathrm{P}$ & $35.90 \mathrm{Q}$ & $40.29 \mathrm{E}$ \\
\hline Mean & $46.00 \mathrm{~A}$ & $43.64 \mathrm{~B}$ & $42.82 \mathrm{C}$ & $41.90 \mathrm{D}$ & $41.13 \mathrm{E}$ & $39.44 \mathrm{~F}$ & \\
\hline
\end{tabular}

Color (Hue angel)

Changes in hue angle values of cucumber fruits are good indicator of senescence data in Table (5) showed 
that the hue angle values of cucumber fruits gradually decreased as the storage turned to slight yellow as the storage period prolonged. These results were true in the two seasons and in agreement with Rageh and Abou-Elwafa (2017).

Concerning the effete of postharvest treatments data showed that all postharvest treatments had significantly higher hue angle values as compared with untreated control. Fruits dipped inpotassium silicate, salicylic acid were the more effective treatments in reducing the loss of hue angle value indicated that fruits retained more green color during storage plus shelf life, followed methyl jasmonate or chitosan with no significant differences them. while lower hue angle value were detected in the untreated control indicated that fruits had less green color, hot water treatments were less effective in this concern. These results were in the two seasons and in agreement with Attia and saleh (2016) for MeJA; Mohamedet al. (2016) for salicylic acid; Ahmed (2015) for chitosan.

Table 5. Effect of some postharvest treatments on color change (Hue angel) of cucumber fruits during cold storage plus shelf life in 2017 and 2018 seasons.

\begin{tabular}{|c|c|c|c|c|c|c|c|}
\hline \multirow{3}{*}{ Treatments } & \multicolumn{6}{|c|}{ Storage period (days) } & \multirow{3}{*}{ Mean } \\
\hline & \multicolumn{6}{|c|}{2017} & \\
\hline & 0 & $\mathbf{0}+2$ & $4+2$ & $8+2$ & $12+2$ & $16+2$ & \\
\hline Hot water & $121.60 \mathrm{~A}$ & $121.00 \mathrm{~B}$ & $120.30 \mathrm{CD}$ & $119.10 \mathrm{GH}$ & $118.10 \mathrm{JK}$ & $116.10 \mathrm{M}$ & $119.40 \mathrm{C}$ \\
\hline $\begin{array}{c}\text { Methyl } \\
\text { Jasmonate }\end{array}$ & $121.60 \mathrm{~A}$ & $121.20 \mathrm{AB}$ & $121.00 \mathrm{~B}$ & $119.60 \mathrm{EF}$ & $118.70 \mathrm{HI}$ & $116.80 \mathrm{~L}$ & $119.80 \mathrm{~B}$ \\
\hline Potassium silicate & $121.60 \mathrm{~A}$ & $121.30 \mathrm{AB}$ & $121.10 \mathrm{~B}$ & $120.20 \mathrm{CD}$ & $119.70 \mathrm{EF}$ & $\begin{array}{l}118.40 \\
\text { IJK }\end{array}$ & $120.40 \mathrm{~A}$ \\
\hline Chitosan & $121.60 \mathrm{~A}$ & $121.20 \mathrm{AB}$ & $121.10 \mathrm{~B}$ & $119.40 \mathrm{EFG}$ & $118.50 \mathrm{IJ}$ & $\begin{array}{c}116.40 \\
\text { LM }\end{array}$ & $119.70 \mathrm{~B}$ \\
\hline Salicylic acid & $121.60 \mathrm{~A}$ & $121.40 \mathrm{AB}$ & $121.20 \mathrm{AB}$ & $120.30 \mathrm{CD}$ & $119.80 \mathrm{DE}$ & $118.50 \mathrm{IJ}$ & $120.50 \mathrm{~A}$ \\
\hline Control & $121.60 \mathrm{~A}$ & $120.40 \mathrm{C}$ & $119.30 \mathrm{FG}$ & $118.00 \mathrm{~K}$ & $116.10 \mathrm{M}$ & $113.00 \mathrm{~N}$ & 118.10 D \\
\hline Mean & $121.60 \mathrm{~A}$ & 121.10 B & $120.70 \mathrm{C}$ & 119.40 D & $118.50 \mathrm{E}$ & $116.50 \mathrm{~F}$ & \\
\hline \multicolumn{8}{|c|}{2018} \\
\hline Hot water & $123.10 \mathrm{~A}$ & $121.50 \mathrm{FG}$ & $122.20 \mathrm{DE}$ & $120.30 \mathrm{JK}$ & $119.30 \mathrm{LM}$ & $117.30 \mathrm{P}$ & $120.60 \mathrm{D}$ \\
\hline $\begin{array}{c}\text { Methyl } \\
\text { Jasmonate }\end{array}$ & $123.10 \mathrm{~A}$ & $122.40 \mathrm{C}-\mathrm{E}$ & $122.60 \mathrm{~B}-\mathrm{D}$ & $121.30 \mathrm{GH}$ & $120.60 \mathrm{IJ}$ & $119.10 \mathrm{M}$ & $121.50 \mathrm{~B}$ \\
\hline Potassium silicate & $123.10 \mathrm{~A}$ & $122.60 \mathrm{~B}-\mathrm{D}$ & $122.80 \mathrm{~A}-\mathrm{C}$ & $121.20 \mathrm{GH}$ & $120.30 \mathrm{JK}$ & $\begin{array}{c}118.40 \\
\text { NO }\end{array}$ & $\begin{array}{c}121.40 \\
\text { BC }\end{array}$ \\
\hline Chitosan & $123.10 \mathrm{~A}$ & $122.60 \mathrm{~B}-\mathrm{D}$ & $122.70 \mathrm{~A}-\mathrm{D}$ & $120.90 \mathrm{HI}$ & $120.00 \mathrm{~K}$ & $117.90 \mathrm{O}$ & 121.20 C \\
\hline Salicylic acid & $123.10 \mathrm{~A}$ & $122.80 \mathrm{~A}-\mathrm{C}$ & $123.00 \mathrm{AB}$ & $121.90 \mathrm{EF}$ & $121.40 \mathrm{FG}$ & $120.10 \mathrm{~K}$ & $122.00 \mathrm{~A}$ \\
\hline Control & $123.10 \mathrm{~A}$ & $119.80 \mathrm{KL}$ & $120.90 \mathrm{HI}$ & $118.50 \mathrm{~N}$ & $116.60 \mathrm{Q}$ & $113.50 \mathrm{R}$ & $118.70 \mathrm{E}$ \\
\hline Mean & $123.10 \mathrm{~A}$ & $121.90 \mathrm{C}$ & $122.40 \mathrm{~B}$ & $120.70 \mathrm{D}$ & $119.70 \mathrm{E}$ & $117.70 \mathrm{~F}$ & \\
\hline
\end{tabular}

Means in the same column having the same letter are not significantly different at 0.05 level by Duncan's multiple rang test.

The reduction of color development in cucumber fruits treated with methyl jasmonate, salicylic acid or potassium silicate could be attributed to the low rate of respiration rate and reduced ethylene production resulted in lower activity of chlorophylls and chlorophyll degradation, so maintained green color of cucumber fruits (Wang and Buta, 1994) for methyl jasmonate and $\mathrm{Wu}$ and $\mathrm{Wu}$ (2001); Ahmed (2015) for salicylic and Mditshwaet al. (2013) for potassium silicate.

\section{Chilling injury (CI):}

Chilling injury symptoms in cucumber fruit appear as surface pitting, followed by large sunken spots, water soaked areas, shriveling, and decay. The symptoms of chilling injury usually become more pronounced after transfer of the fruit from a chilling temperature to a warmer temperature. Cucumber fruits in this study were evaluated for the severity of appearance of CI 2 days following transfer from $5^{\circ} \mathrm{C}$ to $15^{\circ} \mathrm{C}$. Chilling injury (surface pitting) may be due to the increase of ethylene evolution and level of amino cyclopropanecarboxlic acid (ACC), putrescine and ascorbic acid. The high concentration of these chemicals in the preicarp tissue induced chilled fruits with pitting appearance (Serrano et al., 1997).

Results in Table (6) indicated that cucumber fruits in all treatments appeared without any symptoms of pitting after 4 days at $5^{\circ} \mathrm{C}+2$ days at $15^{\circ}$ C. The differences in the severity of CI among different treatments became more appearance as time progressed. Traces of chilling injury were found on the skin of cucumber in the untreated control on the eight day and the symptoms of chilling injury became more apparent in these cucumbers after 12 days of storage at $5^{\circ} \mathrm{C}+2$ day at $15^{\circ} \mathrm{C}$, reached the severe stage by $16^{\text {th }}$ days at $5^{\circ} \mathrm{C}+2$ day at $15^{\circ} \mathrm{C}$ (severity of $\mathrm{CI}$ at $5^{\circ} \mathrm{C}$ ). However, cucumber fruits treated with methyl jasmonate, potassium silicate and salicylic acid did not develop any symptoms of CI during all storage period plus shelf life. The onset of CI symptoms in cucumber fruits was delayed by hot water and chitosan treatments. However these 
treatments reduced the rate of CI development. These results were true in the two seasons and in agreement with (Mohamed et al., 2016) whofound that $\mathrm{Si}$ improved the levels of flavonoids and phenolics, they had an adverse effect on fruit by increasing the occurrences of chilling injury. However, increased levels of flavonoids and phenolics in response to high concentrations of Si suggest that Si may be involved in modulating enzyme. The impaired visual fruit quality after postharvest silicon applications should be considered as a method to reduce postharvest chilling injury.

Table 6.Effect of some postharvest treatments on chilling injury (score) of cucumber fruits during cold storage plus shelf life in 2017 and 2018 seasons.

\begin{tabular}{|c|c|c|c|c|c|c|c|}
\hline \multirow{3}{*}{ Treatments } & \multicolumn{6}{|c|}{ Storage period (days) } & \multirow{3}{*}{ Mean } \\
\hline & \multicolumn{6}{|c|}{2017} & \\
\hline & $\mathbf{0}$ & $\mathbf{0 + 2}$ & $4+2$ & $8+2$ & $12+2$ & $16+2$ & \\
\hline Hot water & $1.00 \mathrm{H}$ & $1.00 \mathrm{H}$ & $1.00 \mathrm{H}$ & $1.00 \mathrm{H}$ & $1.67 \mathrm{G}$ & $2.33 \mathrm{E}$ & $1.33 \mathrm{C}$ \\
\hline Methyl Jasmonate & $1.00 \mathrm{H}$ & $1.00 \mathrm{H}$ & $1.00 \mathrm{H}$ & $1.00 \mathrm{H}$ & $1.00 \mathrm{H}$ & $1.00 \mathrm{H}$ & $1.00 \mathrm{D}$ \\
\hline Potassium silicate & $1.00 \mathrm{H}$ & $1.00 \mathrm{H}$ & $1.00 \mathrm{H}$ & $1.00 \mathrm{H}$ & $1.00 \mathrm{H}$ & $1.00 \mathrm{H}$ & $1.00 \mathrm{D}$ \\
\hline Chitosan & $1.00 \mathrm{H}$ & $1.00 \mathrm{H}$ & $1.00 \mathrm{H}$ & $1.00 \mathrm{H}$ & $2.00 \mathrm{~F}$ & $3.00 \mathrm{C}$ & $1.50 \mathrm{~B}$ \\
\hline Salicylic acid & $1.00 \mathrm{H}$ & $1.00 \mathrm{H}$ & $1.00 \mathrm{H}$ & $1.00 \mathrm{H}$ & $1.00 \mathrm{H}$ & $1.00 \mathrm{H}$ & $1.00 \mathrm{D}$ \\
\hline Control & $1.00 \mathrm{H}$ & $1.00 \mathrm{H}$ & $1.00 \mathrm{H}$ & $2.67 \mathrm{D}$ & $4.33 \mathrm{~B}$ & $5.00 \mathrm{~A}$ & $2.50 \mathrm{~A}$ \\
\hline \multirow[t]{2}{*}{ Mean } & 1.00 D & $1.00 \mathrm{D}$ & $1.00 \mathrm{D}$ & $1.28 \mathrm{C}$ & $1.83 \mathrm{~B}$ & $2.22 \mathrm{~A}$ & \\
\hline & \multicolumn{6}{|c|}{2018} & \\
\hline Hot water & $1.00 \mathrm{~F}$ & $1.00 \mathrm{~F}$ & $1.00 \mathrm{~F}$ & $1.00 \mathrm{~F}$ & $2.00 \mathrm{DE}$ & $2.67 \mathrm{C}$ & $1.44 \mathrm{~B}$ \\
\hline Methyl Jasmonate & $1.00 \mathrm{~F}$ & $1.00 \mathrm{~F}$ & $1.00 \mathrm{~F}$ & $1.00 \mathrm{~F}$ & $1.00 \mathrm{~F}$ & $1.00 \mathrm{~F}$ & $1.00 \mathrm{C}$ \\
\hline Potassium silicate & $1.00 \mathrm{~F}$ & $1.00 \mathrm{~F}$ & $1.00 \mathrm{~F}$ & $1.00 \mathrm{~F}$ & $1.00 \mathrm{~F}$ & $1.00 \mathrm{~F}$ & $1.00 \mathrm{C}$ \\
\hline Chitosan & $1.00 \mathrm{~F}$ & $1.00 \mathrm{~F}$ & $1.00 \mathrm{~F}$ & $1.00 \mathrm{~F}$ & $1.67 \mathrm{E}$ & $2.67 \mathrm{C}$ & $1.39 \mathrm{~B}$ \\
\hline Salicylic acid & $1.00 \mathrm{~F}$ & $1.00 \mathrm{~F}$ & $1.00 \mathrm{~F}$ & $1.00 \mathrm{~F}$ & $1.00 \mathrm{~F}$ & $1.00 \mathrm{~F}$ & $1.00 \mathrm{C}$ \\
\hline Control & $1.00 \mathrm{~F}$ & $1.00 \mathrm{~F}$ & $1.00 \mathrm{~F}$ & $2.33 \mathrm{CD}$ & $4.00 \mathrm{~B}$ & $5.00 \mathrm{~A}$ & $2.39 \mathrm{~A}$ \\
\hline Mean & $1.00 \mathrm{D}$ & $1.00 \mathrm{D}$ & $1.00 \mathrm{D}$ & $1.22 \mathrm{C}$ & $1.78 \mathrm{~B}$ & $2.22 \mathrm{~A}$ & \\
\hline
\end{tabular}

Means in the same column having the same letter are not significantly different at 0.05 level by Duncan's multiple rang test.

Wang (2006) found that methyl jasmonate enhance the resistance of tissues to chilling injury by increasing the gene expression of heat shock proteins, pathogenesis-related proteins, and alternative oxidase. Also, methyl jasmonate increased antioxidant capacities, antioxidant enzyme activities, and free radical scavenging capacities in the tissues.

Sayyari et al. (2011) found that SA can play a role in inducing PR gene transcription and protect against chilling injury most likely arises from reports that SA can inhibit catalase activity in several plant species. Four results showed that cat 1 expression was weakly inhibited by MeSA. As a result of the inhibition of catalase by $\mathrm{SA}$, the amount of $\mathrm{H}_{2} \mathrm{O}_{2}$ in cells may increase. The increase in reactive oxygen species (ROS) plays a role in the induction of defense responses such as PR-protein gene expression. The increase in cat 1 transcripts in MeJA-treated fruit after day 3 may result from $\mathrm{H}_{2} \mathrm{O}_{2}$ accumulation, which subsequently induces the transcription of catalase via a feedback mechanism.

The effect of hot water treatment in delaying the onset of CI may be due to that heat treatment increased polyamines concentration (Putrescince, SpermiddineandSpermine) which protect the integrity of membranes and then alleviated CI (Mirdehghan et al., 2007). Also, Klein and Lurie (1991) found that heat treatment induce the production of heat chock proteins, which confer enhanced tolerance to chilling temperature
Tareen et al. (2012b) showed that chilling temperature not only caused the appearance of external injury symptoms but also affected internal quality and chemical composition of the commodity. Treatments that can alleviate chilling injury should also improve the internal quality of these chillingsensitive fresh produce as well as that of fresh-cut products.

\section{Fruit firmness:}

Data in Table (7) reveled that fruit firmness was gradually and consistently decreased with the prolongation of storage period and reached the lowest value at the end of storage period. The losses of fruit firmness are associated with changes in cell wall mechanical strength during storage (Valero \& Serrano, 2010). Loss of fruit firmness starts with the conversion of insoluble protopectin into water soluble pectin by breakdown of the middle lamellae, which is intimately related to hydrolytic enzyme, so rigidity of cell walls was reduced and led to fruit softening (Pressey\&Avants, 1973). In addition, firmness of fruit depends primarily on the weight loss rate (BenYehoshua et al., 1983).

These results were true in the two seasons and are in agreement with those obtained by Ragehand AbouElwafa (2017).

Concerning the effect of postharvest treatments, data revealed that all postharvest treatments had a significant effect on fruit firmness as compared with untreated control during storage plus shelf life. However, cucumber fruits treated with 
potassium silicate or salicylic acid were the most effective treatment in reducing the loss of firmness during storage with no significant differences between them in the two seasons, followed by methyl jasmonate treatment and chitosan treatments.Hot water less effective in this concern. The lowest value of fruit firmness was obtained from untreated control. These results were achieved in the two seasons and were in agreement with Yassinetal., (2017) for hot water; Rageh and Abou-Elwafa (2017) for jasmine oil; Mohamed et al. (2016) for salicylic acid and Afifi (2016) for potassium silicate.

Table 7. Effect of some postharvest treatments on fruit firmness $\left(\mathrm{LP} / \mathrm{in}^{2}\right)$ of cucumber fruits during cold storage plus shelf life in 2017 and 2018 seasons.

\begin{tabular}{|c|c|c|c|c|c|c|c|}
\hline \multirow{3}{*}{ Treatments } & \multicolumn{6}{|c|}{ Storage period (days) } & \multirow{3}{*}{ Mean } \\
\hline & \multicolumn{6}{|c|}{2017} & \\
\hline & $\mathbf{0}$ & $\mathbf{0 + 2}$ & $4+2$ & $8+2$ & $12+2$ & $16+2$ & \\
\hline Hot water & $7.62 \mathrm{~A}$ & $7.07 \mathrm{~A}-\mathrm{F}$ & $6.70 \mathrm{~B}-\mathrm{J}$ & $6.40 \mathrm{E}-\mathrm{K}$ & $6.12 \mathrm{G}-\mathrm{L}$ & $5.62 \mathrm{~K}-\mathrm{M}$ & $6.59 \mathrm{C}$ \\
\hline Methyl Jasmonate & $7.62 \mathrm{~A}$ & 7.32 A-D & $6.80 \mathrm{~A}-\mathrm{H}$ & $6.50 \mathrm{D}-\mathrm{J}$ & $6.29 \mathrm{~F}-\mathrm{K}$ & $6.03 \mathrm{H}-\mathrm{L}$ & $6.76 \mathrm{BC}$ \\
\hline Potassium silicate & $7.62 \mathrm{~A}$ & $7.50 \mathrm{AB}$ & 7.31 A-D & $7.12 \mathrm{~A}-\mathrm{F}$ & $6.93 \mathrm{~A}-\mathrm{G}$ & 6.75 B-I & $7.21 \mathrm{~A}$ \\
\hline Chitosan & $7.62 \mathrm{~A}$ & 7.20 A-E & $6.90 \mathrm{~A}-\mathrm{G}$ & 6.63 C-J & $6.30 \mathrm{~F}-\mathrm{K}$ & $5.90 \mathrm{I}-\mathrm{L}$ & $6.76 \mathrm{BC}$ \\
\hline Salicylic acid & $7.62 \mathrm{~A}$ & $7.40 \mathrm{~A}-\mathrm{C}$ & $7.24 \mathrm{~A}-\mathrm{E}$ & $7.00 \mathrm{~A}-\mathrm{F}$ & $6.80 \mathrm{~A}-\mathrm{H}$ & 6.52 D-J & $7.10 \mathrm{AB}$ \\
\hline Control & $7.62 \mathrm{~A}$ & $6.90 \mathrm{~A}-\mathrm{G}$ & $6.32 \mathrm{~F}-\mathrm{K}$ & $5.84 \mathrm{~J}-\mathrm{L}$ & $5.40 \mathrm{LM}$ & $4.90 \mathrm{M}$ & $6.16 \mathrm{D}$ \\
\hline Mean & $7.62 \mathrm{~A}$ & $7.23 \mathrm{~B}$ & $6.88 \mathrm{C}$ & 6.58 CD & $6.31 \mathrm{D}$ & $5.95 \mathrm{E}$ & \\
\hline \multicolumn{8}{|c|}{2018} \\
\hline Hot water & $7.74 \mathrm{~A}$ & $7.19 \mathrm{~A}-\mathrm{G}$ & $6.82 \mathrm{~B}-\mathrm{IJ}$ & $6.52 \mathrm{E}-\mathrm{L}$ & $6.24 \mathrm{H}-\mathrm{M}$ & $5.74 \mathrm{~L}-\mathrm{N}$ & $6.71 \mathrm{~B}$ \\
\hline Methyl Jasmonate & $7.74 \mathrm{~A}$ & $7.42 \mathrm{~A}-\mathrm{D}$ & 6.90 A-I & $6.60 \mathrm{D}-\mathrm{L}$ & $6.39 \mathrm{G}-\mathrm{L}$ & $6.13 \mathrm{I}-\mathrm{M}$ & $6.86 \mathrm{~B}$ \\
\hline Potassium silicate & $7.74 \mathrm{~A}$ & $7.65 \mathrm{AB}$ & 7.46 A-D & $7.27 \mathrm{~A}-\mathrm{F}$ & $7.08 \mathrm{~A}-\mathrm{H}$ & 6.90 A-I & $7.35 \mathrm{~A}$ \\
\hline Chitosan & $7.74 \mathrm{~A}$ & $7.32 \mathrm{~A}-\mathrm{E}$ & $7.02 \mathrm{~A}-\mathrm{H}$ & 6.75 C-K & $6.42 \mathrm{~F}-\mathrm{L}$ & $6.02 \mathrm{~J}-\mathrm{M}$ & $6.88 \mathrm{~B}$ \\
\hline Salicylic acid & $7.74 \mathrm{~A}$ & $7.55 \mathrm{ABC}$ & 7.39 A-D & $7.15 \mathrm{~A}-\mathrm{G}$ & 6.95 A-I & 6.67 D-K & $7.24 \mathrm{~A}$ \\
\hline Control & $7.74 \mathrm{~A}$ & 6.99 A-I & $6.41 \mathrm{~F}-\mathrm{L}$ & $5.93 \mathrm{~K}-\mathrm{M}$ & $5.49 \mathrm{MN}$ & $4.99 \mathrm{~N}$ & $6.26 \mathrm{C}$ \\
\hline Mean & $7.74 \mathrm{~A}$ & $7.35 \mathrm{~B}$ & $7.00 \mathrm{C}$ & 6.70 CD & $6.43 \mathrm{D}$ & $6.08 \mathrm{E}$ & \\
\hline
\end{tabular}

Means in the same column having the same letter are not significantly different at 0.05 levels by Duncan's multiple rang test.

Xing et al., 2011 found that chitosan treatment on pepper fruit had significantly lower malondialdehyde (MDA) contents and relative leakage rates, as an indicator of membrane integrity, than the control fruit, indicating that higher membrane integrity was maintained.

The favorable effect of MeJA on maintained fruit firmness Feng et al. (2003) reveled that MeJA maintained higher pectinasterase and polyglacturonase activities, thereby preventing the development of fresh firmness of peaches. Also, MeJA induce synthesis of abscisic acid and polyamines which act as free radical scavengers and membrane stabilizer as an indicator of membrane integrity were maintained (Wang, 2006).

Tesfay et al. (2011) reported that silicontreated fruit had lower electrolyte leakage compared with the control, possibly due to Si deposition between cell wall and cell membrane, maintaining a barrier against solute leakage. Also, Si may enhance activity of chitinases, peroxidase and polyphenol oxidases and increased formation deposition of callose and hydrogenperoxidesalso, silicon application improved strength and rididity of tissue (Liang et al., 2007).

In general, the interaction between postharvest treatments and storage period was significant in the two seasons. After 16 days of storage at $5^{\circ} \mathrm{C}+2$ days at $15^{\circ} \mathrm{C}$, data revealed that potassium silicate or salicylic acid gave the highest values of fruit firmness with no significant differences between them in the two seasons.

\section{Flavor}

Data in table (8) showed that there were significant differences in flavor of cucumber fruits during storage plus shelf life. All used treatments did not present apparent changes in their flavor till 4 days at $5^{\circ} \mathrm{C}+2$ days at $15^{\circ} \mathrm{C}$. Flavor was then decreased as the storage period was prolonged in the two seasons.

Concerning the effect of postharvest treatments, data revealed that there were significant differences between postharvest treatments in flavor of cucumber fruits during storageplus shelf life. In general, all treatments gave higher score in flavor as compared with untreated control except methyl jasmonate treatment. However, cucumber fruits dipped in chitosan, salicylic acid and potassium silicate were the most effective treatments in maintaining the flavor in fruits with no significant differences between them during storage plus shelf life followed by chitosn treatment. The lowest score in flavor was obtained from methyl jasmonate and untreated control.

Regarding the interaction between postharvest treatments and storage periods, data showed that cucumber fruits dipped in potassium silicate and salicylic acid treatments did not appear changes in their flavor till 12 days, at $5^{\circ} \mathrm{C}+2$ days at 
$15^{\circ} \mathrm{C}$ and give typical flavor cucumber fruits at the end of storage plus shelf life, while fruit dipped in hot water and chitosan independently showed a slight changes. Moreover, methyl jasmonate or untreated control resulted in non-typical flavor cucumber after 16 days at $5^{\circ} \mathrm{C}+2$ days at $15^{\circ} \mathrm{C}$. These results were true in the two seasons.

Table 8. Effect of some postharvest treatments on flavor (score)of cucumber fruits during cold storage plus shelf life in 2017 and 2018 seasons.

\begin{tabular}{|c|c|c|c|c|c|c|c|}
\hline \multirow{3}{*}{ Treatments } & \multicolumn{6}{|c|}{ Storage period (days) } & \multirow{3}{*}{ Mean } \\
\hline & \multicolumn{6}{|c|}{2017} & \\
\hline & $\mathbf{0}$ & $0+2$ & $4+2$ & $8+2$ & $12+2$ & $16+2$ & \\
\hline Hot water & $5.00 \mathrm{~A}$ & $5.00 \mathrm{~A}$ & $5.00 \mathrm{~A}$ & $4.67 \mathrm{AB}$ & $4.00 \mathrm{CD}$ & $3.67 \mathrm{D}$ & $4.56 \mathrm{~B}$ \\
\hline Methyl Jasmonate & $5.00 \mathrm{~A}$ & $5.00 \mathrm{~A}$ & $5.00 \mathrm{~A}$ & $3.00 \mathrm{E}$ & $2.33 \mathrm{~F}$ & $1.00 \mathrm{G}$ & $3.56 \mathrm{D}$ \\
\hline Potassium silicate & $5.00 \mathrm{~A}$ & $5.00 \mathrm{~A}$ & $5.00 \mathrm{~A}$ & $5.00 \mathrm{~A}$ & $5.00 \mathrm{~A}$ & $4.67 \mathrm{AB}$ & $4.94 \mathrm{~A}$ \\
\hline Chitosan & $5.00 \mathrm{~A}$ & $5.00 \mathrm{~A}$ & $5.00 \mathrm{~A}$ & $5.00 \mathrm{~A}$ & $4.33 \mathrm{BC}$ & $3.67 \mathrm{D}$ & 4.67 B \\
\hline Salicylic acid & $5.00 \mathrm{~A}$ & $5.00 \mathrm{~A}$ & $5.00 \mathrm{~A}$ & $5.00 \mathrm{~A}$ & $5.00 \mathrm{~A}$ & $4.67 \mathrm{AB}$ & $4.94 \mathrm{~A}$ \\
\hline Control & $5.00 \mathrm{~A}$ & $5.00 \mathrm{~A}$ & $5.00 \mathrm{~A}$ & $3.67 \mathrm{D}$ & $4.00 \mathrm{CD}$ & $2.33 \mathrm{~F}$ & $4.17 \mathrm{C}$ \\
\hline Mean & $5.00 \mathrm{~A}$ & $5.00 \mathrm{~A}$ & $5.00 \mathrm{~A}$ & $4.39 \mathrm{~B}$ & $4.11 \mathrm{C}$ & 3.33 D & \\
\hline \multicolumn{8}{|c|}{2018} \\
\hline Hot water & $5.00 \mathrm{~A}$ & $5.00 \mathrm{~A}$ & $5.00 \mathrm{~A}$ & $4.67 \mathrm{AB}$ & $4.33 \mathrm{BC}$ & $3.67 \mathrm{DE}$ & 4.61B \\
\hline Methyl Jasmonate & $5.00 \mathrm{~A}$ & $5.00 \mathrm{~A}$ & $5.00 \mathrm{~A}$ & $3.33 \mathrm{E}$ & $2.67 \mathrm{~F}$ & $1.33 \mathrm{G}$ & $3.72 \mathrm{D}$ \\
\hline Potassium silicate & $5.00 \mathrm{~A}$ & $5.00 \mathrm{~A}$ & $5.00 \mathrm{~A}$ & $5.00 \mathrm{~A}$ & $5.00 \mathrm{~A}$ & $4.67 \mathrm{AB}$ & $4.94 \mathrm{~A}$ \\
\hline Chitosan & $5.00 \mathrm{~A}$ & $5.00 \mathrm{~A}$ & $5.00 \mathrm{~A}$ & $5.00 \mathrm{~A}$ & $4.33 \mathrm{BC}$ & $3.67 \mathrm{DE}$ & 4.67 B \\
\hline Salicylic acid & $5.00 \mathrm{~A}$ & $5.00 \mathrm{~A}$ & $5.00 \mathrm{~A}$ & $5.00 \mathrm{~A}$ & $5.00 \mathrm{~A}$ & $4.67 \mathrm{AB}$ & $4.94 \mathrm{~A}$ \\
\hline Control & $5.00 \mathrm{~A}$ & $5.00 \mathrm{~A}$ & $5.00 \mathrm{~A}$ & $4.00 \mathrm{CD}$ & $3.33 \mathrm{E}$ & $2.33 \mathrm{~F}$ & $4.11 \mathrm{C}$ \\
\hline Mean & $5.00 \mathrm{~A}$ & $5.00 \mathrm{~A}$ & $5.00 \mathrm{~A}$ & 4.50 B & $4.11 \mathrm{C}$ & $3.39 \mathrm{D}$ & \\
\hline
\end{tabular}

Means in the same column having the same letter are not significantly different at 0.05 levels by Duncan's multiple rang test.

\section{Conclusion}

From the previous results, it could be conclude that cucumber fruits dipped in salicylic acid or potassium silicate were the most effective treatments in maintaining fruit quality, give typical flavor fruits and gave fruits without decay or chilling injury symptoms and gave good appearance till16 days at $5^{\circ} \mathrm{C}$ plus two days at $15^{\circ} \mathrm{C}$.

\section{References}

Abd El-Rahman, S.Z. (2001). Physiological studies on developmental stages, different wrapping films and cold storage of eggplant fruits. J. Agric. Sci., Mansoura Univ., 26(11):7007-7022.

Afifi, E.H.E. (2016). Effect of some pre and postharvest treatments on storability of strawberry fruits. M.Sc., Fac. Of Agric., Ain Shams Univ.

Ahmed, N.M.H. (2015). Effect of some postharvest treatments on sweet pepper fruit quality.M.Sc. thesis, Faculty of agriculture, Ain Shams University.

Ali, A.; M.T.M. Muhammad; K. Sijam and Y. Siddiqui (2011).Effect of chitosan coatings on the physicochemical characteristics of Eksotika II papaya (Carica papaya L.) fruit during cold storage. Food Chem. 124, 620-626.

Asghari, M. and M.S. Aghdam (2010).Impact of salicylic acid on postharvest physiology of horticultural crops. Trends in Food Sci. and Techno., 21, 502- 509.
Attia, M.M. and S.M.M. Saleh (2016).Using of hot water and methyl jasmonate treatments for reducing chilling injuries and keeping quality of okra pods during cold storage. Egypt .J. Appl. Sci., 31(11) 345-360.

Baldwin, E.A.; M.O. Nisperos-Carriedo\& R.A. Baker (1995).Use of edible coating for lightly processed fruits and vegetables. Hort. Science, 30, 35-38.

Ben-Yehoshua, S.;B. Shapirom; Z.Chen and S. Lurie (1983). Mode of action of plastic film in extending life of lemon and Bell pepper fruits by alleviation of water stress. Plant Physiology, 73, 87-93.

Cantwell, M. and X. Nie (1992). Use of heat treatment to control postharvest pathogens on tomatoes and melons.Proceeding of Organic Farming Symposium.Univ. of California Division of Agriculture and natural resources, Asilomar, California.Publication 3356, pp.96-101.

Cantwell, M.; X. Nie and G. Hong (2009).Impact of storage conditions on grape and tomato quality. Postharvest Symposium Antalya, Turkey, April 812.

Crusciol, C.A.C.; A.L. Pulz; L.B. Lemos; R.P. Soratto\& P.P. Lima (2009). Effects of silicon and drought stress on tuber yield and leaf biochemical characteristics in potato. Crop Sci. 49:949-954.

Ding C.K.; C.Y. Wang; K.C. Gross and D.L. Smith(2002). Jasmonate and salicylate induce the 
expression of pathogenesis-related protein genes and increase resistance to chilling injury in tomato fruit. Planta 214:895-901.

Ding, Z.; S. Tian; X. Meng and Y. XU (2009). Hydrogen peroxide is correlated with browning in peach fruit stored at low temperature. Frontiers of Chemical Engineering, 3, 363-374.

Dong, H.; Y. Jiang; Y. Wang.; R. Liu and H. Guan (2004).Effects of hot water immersion on storage quality of fresh broccoli heads.Food Technol. Biotechnol. 42 (2) 135-139.

EL-Badawy, M.S.A. (2014).Effect of Spray with some safety compounds on growth and productivity of some strawberry cultivars.M.Sc.Thesis, Fac. Agric., Banha Univ., Egypt, 76 p.

Epstein, E. (2009). Silicon: its manifold roles in plants. Ann. Appl. Bio. 155:155-160.

Fard,K.G.; M. Kamari; Ghasemnezhad and R.F. Ghazvini (2010).Effect of chitosan coating on weight loss and postharvest quality of Green pepper (Capsicum annum L.)Fruits.Acta Hort.877, ISHS.

Feng, L.; Y.H. Zhang; Y.F. Zhang; F. Wang; L. Zhang and Z.X. Lu (2003). Methyl jasmonate reduced chilling injury and maintains postharvest quality in peaches. Sci. Agric. Sin., 11:1246-1252.

Ghasemnezhad, M. and M. Javaherdashti (2008).Effect of Methyl jasmonate treatment on antioxidant capacity, internal quality and postharvest life of raspberry fruit. Caspian $\mathrm{J}$. Environ. Sci., 6 (1):73-78.

González-aguilar G.A.; L. Gayosso; R. Cruz; J. Fortiz; R. Báez\& C.Y. Wang (2000). Polyamines induced by hot water treatments reduce chilling injury and decay in pepper fruit. Posthar.Bio.Techn. 18:1926.

Hamdy, E.M.E.; M. Hassan and A.S.H. Atress (2015).Maintaining quality of mixed load of fresh fruits and vegetables with volatile compounds of jasmine oil. Egypt. J. Agric. Res. 93(3):269-287.

Hardenburg, R.E.; A.E. Watada and C.Y. Wang (1986). The commercial storage of fresh fruits, vegetables, florist and nursery stocks.US Dept. Agric. Handb.66.pp130.

Harvey, T.; J.R. Chan and E. Linse (1989).Condition cucumber for Quarantine heat treatments. HortScince. 24 (6): 958-989.

Ilic, Z.; Y.Polevaya; A.S. Tuvia; A. Copeland E.A. Fallik (2001). A short pre storage hot water rinse and brushing reduces decay development in tomato, while maintaining its quality. Tropical Agriculture Research Ext., 4: 1-6.

Kaluwa, K.; I. Bertling; J.P. Bower and S.Z. Tasfay (2010). Silicon application effects on "Hass" avocado fruit physiology. South Africa Avocado Growers Association, Year Book, 33 pp.
Klein, J.D. and S. Lurie (1991).Postharvest heat treatment and fruit quality. Postharvest News and Information, 2: 15-19.

Liang, Y.; W. Sun; Y. Zhu \& P. Christie (2007). Mechanisms of siliconmediated alleviation of abiotic stresses in higher plants: A Review. Envir.Pollut. 147:422-428.

Mao, L.C.; C.Z. Wang; C.C. Zhu; and H.Q. Pang (2007).Involvement of phospholipase D and lipoxygenase in response to chilling stress in postharvest cucumber fruits. Plant Sci. 172, 400405.

Mayer, A.M. (1987). Polyphenol oxidases in plants recent progress.Phytochemistry, 26, 11-20.

McGuire, R.G. (1992). Reporting of objective color measurements.HortScience, 27:1254-1255.

Mditshwa, A.; J.P. Bower; I. Bertling; N. Mathaba and S.Z. Tesfay (2013). The potential of postharvest silicon dips to regulate phenolics in citrus peel as a method to mitigate chilling injury in lemons. Afr. J. of Biotech. V: 12(13), pp. 1482-1489.

MengMeng, Y.; G. Lipu; W. Qing; P. Jieand Na. (2012).Effect of chitosan coating on chilling injury in summer squash. J.of HenanAgric.Sci.; 41(10):114-117.12 ref.

Mirdehghan, S.H.; M. Rahemi; D. Martinez-Romero; F. Guillen\& J.M. Valverde (2007). Reduction of pomegranate chilling injury storage after heat treatment: role of polyamines. Posth.Biol. and Techn. 44:19-25.

Mohamed, M.A.A.; A.F. Abd El-Khalek; H.G. Elmehrat and G.A. Mohamed (2016). Pre-storage application of antioxidant alleviates chilling injury and maintains quality of Valencia orange fruit stored at low temperature. Egypt. J. Hort. Vol. 43, No. 1, pp. 175-193.

Pressey, R. and J.K. Avants (1973).Separation and characterization of endopolygalacturonase and exopolygalacturonase from peaches. Plant Physiology, 52, 252-256.

Rageh, M.A. and S.M. Abou-Elwafa (2017).Effect of jasmine oil and active dry yeast as a preharvest spray on alleviating chilling injury in cucumber fruits during cold storage. Middle East J. Agric. Res., 6(4): 1144-1154.

Sato,

Y.;T.Murakami;H.Funatsuki;S.Matsuba;H.Saruya ma\&M.Tanida (2001). Heat shock-mediated APX gene expression and protection against chilling injury in rice seedlings. J. Exper. Bot. 52:145-151.

Sayyari, M.; C. Salvador; V. Danie; M.D.M. Huertas\& M. Serran (2011). Acetyl salicylic acid alleviates chilling injury and maintains nutritive and bioactive compounds and antioxidant activity during postharvest storage of pomegranates. Posth. Biol. and Techn., 60, 136-142.

Sembdner, G. and B. Parthier (1993). The biochemistry and the physiological and molecular 
actions of jasmonates.A.Rev.Pl.Physiol.44,569589.

Serrano, M.; M.C. Martianez-Madrid; M.T. Pretel; F. Piquelne and F. Remojaro (1997). Modified atmosphere packing minimizes increases in putrescine and abscisic acid levels caused by chilling injury in pepper fruit. J.A.gric. Food chem., 45:1668-1672.

Shehata, S.A.; A.G. Behairy and Z.F. Fawzy (2004). Effect of some organic manures on growth and chemical composition of sweet pepper (Capsicum annuит L.) grown in a sandy soil. Egypt. J. Agric. Res., 82(2): 57-71.

Shehata, S.A.; M.Y. Hshem and M.M. Attia (2011).Combined application of hot water and low temperature conditioning reduced chilling injury and maintained quality of cucumber fruits during storage. Annals of Agric. Sci., Moshtohor, 49(3):27-34.

Shiri, M.A.; D. Bakhshi; M. Ghasemnezhad; M. Dadi; A. Papachatzism\& H. Kalorizou (2013). Chitosan coating improves the shelf life and postharvest quality of table grape (Vitisvinifera)cultivar Shahroudi. Turk. J. Agric. for 37,148-156.

Shoor, M. (2010).Preharvest citric acid application extended postharvest vase life of Lilium cv. Brunello. $28^{\text {th }}$ International Horticultural Congress.

Snedecor, G.W. and W.G. Cochran, 1980. Statistical methods. 8th Ed., Iowa State Univ. Press, Ames, Iowa, USA., 476 p.

Tarabih, M.E.; E.F. El-Fryan and M.A. El-Metwally (2014).Physiological pathological impactes of potassium silicate on storability of anna apple fruits. Am. J. Plant Physiol., 9:52-67.

Tareen, M.J.; N.A. Abbasi and I.A. Hafiz (2012a).Effect of salicylic acid treatments of storage life of peach fruits cv. 'Flordaking'.Pakistan Journal of Botany, 44 (I), 119- 124.

Tareen, M.J.; N.A. Abbasi and I.A. Hafiz (2012b). Postharvest application of salicylic acid enhanced antioxidant enzyme activity and maintained quality of peach cv. 'Flordaking' fruit during storage. ScientiaHorti., 142, 221-228.

Tesfay, S.; I. Bertling\& J. Bower (2011). Effects of postharvest potassium silicate application on phenolics and other anti-oxidant systems aligned to avocado fruit quality. Posthar.Bio.Techn. 60(2): 92-99.

Valero, D. and Serrano, M. (2010).Postharvest biology and technology for preserving fruit
quality.CRC-Taylor and Francis, Boca Raton, USA.

Velickova, E.; E. Winkelhausen; S. Kuzmanova; V.D. Alves and M. Moldao-Martins (2013).Impact of chitosan edible coatings on the quality of fresh strrowberries (Fragaria x ananassa cv. Camarosa) under commercial storage condations. LWT-Food, Sci. and Technol., 52(2):80-92.

Waller, R.A. and D.B. Duncan, 1969. A buyes rule for the symmetric multiple comparison problems. Amer. State. Assoc. J., 64:1484-1503.

Wang, C.Y. (2006). Reducing chilling injury and maintaining quality of horticultural crops with natural products and their derivatives.IV International Conference on Managing Quality in Chains-The Integrated View on Fruits and Vegetables Quality 712, 285-290.

Wang, C.Y. and J.G. Buta (1994). Methyl jasmonate reduces chilling injury in Cucurbitapepo through its regulation of abscisic acid and polyamine levels. Environmental \& Expt. Bot. 34:427-432.

Wang, C.Y. and L. Qi (1997). Modified atmosphere packaging alleviates chilling injury in cucumbers. Posth.Biol. Technol. 10:195-200.

Wills, R., T. Lee, D. Graham, B. McGlasson, and E. Hall (1981). Postharvest: An introduction to the physiology and handling of fruit and vegetables. New South Wales University Press, Kensington, $176 \mathrm{pp}$.

Wu, P. and L. Wu (2001).Effect of salicylic acid on shelf life of broccoli.Postharvest handling of fresh vegetables. Proceedings of a workshop held in Beijing, China, 9-11 May 2001.

Xing, Y.G.; X.H. Li; Q.L. Xu; J. Yung; Y.Q.Lu \& Y. Tang (2011). Effect of chitosan coating enriched with cinnamon oil on qualitative properties of sweet pepper (Capsicum annum L.) Food Chem. 124, 1443-1450.

Yang, Z.F.; S.F. Cao; Y.H. Zheng\& Y.M. Jiang (2012).Combined salicylic acid and ultrasound treatments for reducing the chilling injury on peach fruit. J. of Agric. and Food Che., 60, 12091212.

Yao, H.J. and S.P. Tian, (2005). Effects of pre- and postharvest application of SA or MeJA on inducing disease resistance of sweet cherry fruit in storage. Posth. Biology and Techn., 35, 253-262.

Yassin, N.M.A.; F.K.M. Shaaban and S.M.A. Eletreby (2017). Affect of postharvest thermal treatments on reducing external chilling injury in avocado'fuerte'cv.fruits. Egypt. J. Agric. Res., 95 (1). 


\section{تأثير بعض معاملات ما بعد الحصاد على تقليل أضرار البرودة لثمار الخيار أثناء التخزين المبرد \\ محسن السيد محمد سعد اليرود \\ قسم بحوث تداول الخضر - معهل بحوث البساتين - مركز البحوث الزراعية بالجيزة.}

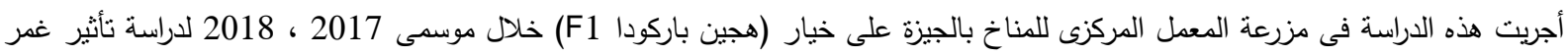

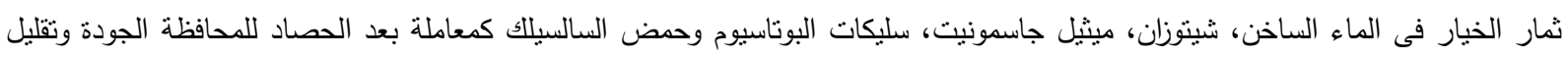

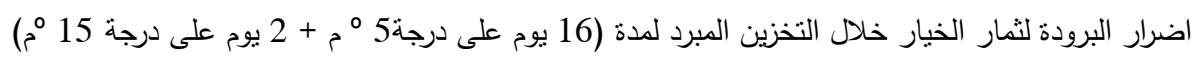

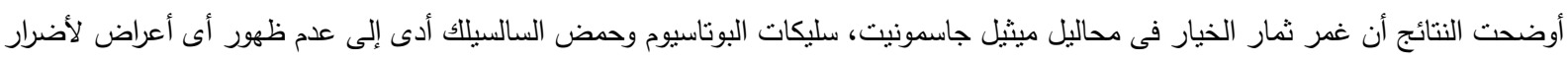

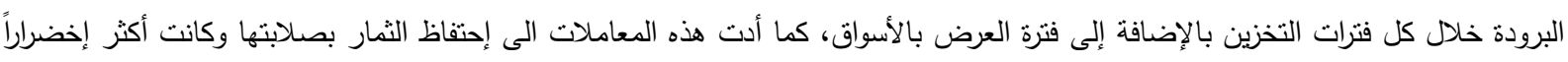

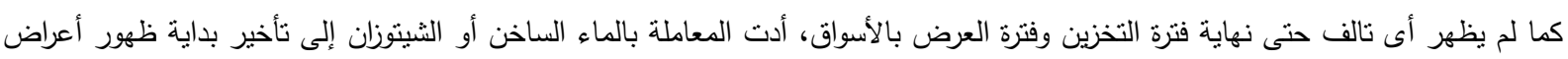
أضرار البرودة كما أدت هذه المعاملات إلى تقليل تطور أضرار البرودة.

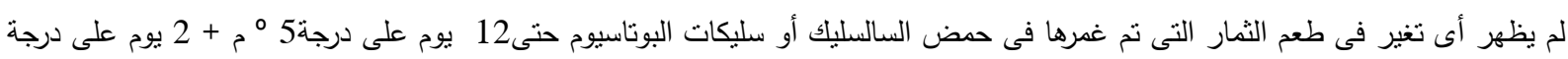

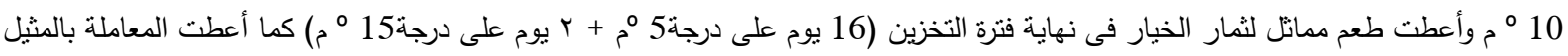

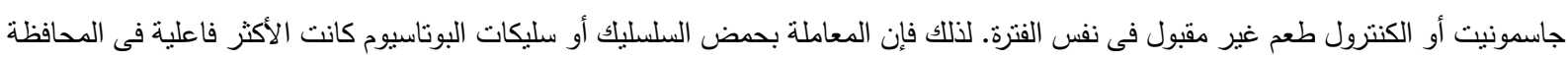

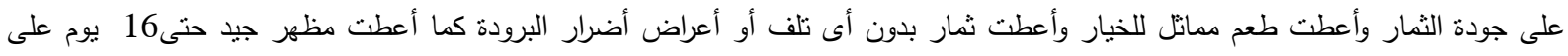

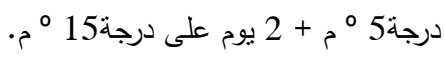

